NBSIR 73.405

\title{
Use of Organic Coatings on the Interior Surfaces of Equestrian Statues at Memorial Bridge Plaza
}

Fielding Ogburn

National Bureau of Standards

Corrosion and Electrodeposition Section

Washington. D. C. 20234

November 1973

Final

Prepared for

National Capital Parks

U. S. Department of Interior

Washington, D. C. 20242 



\section{USE OF ORGANIC COATINGS ON THE INTERIOR SURFACES OF EQUESTRIAN STATUES AT MEMORIAL BRIDGE PLAZA}

Fielding 0gburn

National Bureau of Standards

Corrosion and Electrodeposition Section

Washington, D. C. 20234

November 1973

Final

Prepared for

National Capital Parks

U. S. Department of Interior

Washington, D. C. 20242

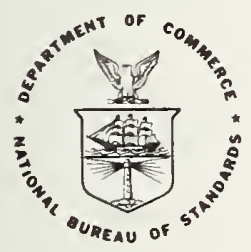

U. S. DEPARTMENT OF COMMERCE, Frederick B. Dent, Secretary

NATIONAL BUREAU OF STANDARDS, Richard W. Roberts, Director 

NATIONAL BUREAU OF STANDARDS

$$
\text { Washington, D.C. } 20234
$$

USE OF ORGANIC COATINGS ON THE INTERIOR SURFACES OF EQUESTRIAN STATUES AT MEMORIAL BRIDGE PLAZA

\section{INTRODUCTION}

In March of 1971, the National Bureau of Standards submitted to National Capital Parks a report outlining a number of methods for the restoration of the equestrian statues at Memoriàr Bridge Plaza. At that time and ever since there have been intermittent discussions of the advisability of applying an organic coating to the interior surfaces in order to retard or prevent deterioration of the statues with time. These discussions have not lead to conclusions clearly acceptable to everybody taking an active interest in the matter. There is an apparent need to make some evaluation of the matter in a systematic way.

This report was prepared by Fielding Ogburn of the Corrosion Section and reviewed by: Elio Passaglia, Chief, Metaliurgy Division; Jerome Kruger, Chief, Corrosion Section; Marion L. Picklesimer, Chief, Mechanical Properties Section; and Paul T. Howard, Structures, Materials, and Life Safety Division.

Drafts of this report were sent to: Mildred Patterson, Materiais Engineer, Dept. of the Navy; Louis D. Fitzgerald, Internation Copper Research Assoc.; Robert Brookshire, Brooktronics Engineering Corp.; and Wijburn A. Boggs, Corrosion Engineer, Lockheed-Georgia Co. Their comments were solicited and given careful consideration. It is our understanding that the opinions of Mrs. Patterson, Mr. Brookshire, and 
Mr. Boggs have been communicated to personnel of National Capital Parks.

\section{The Problem}

The interiors of the statues have a rather hostile environment. The temperature is continually cycling between night and daytime conditions and between summer and winter conditions. The temperature range extends from below freezing to that produced by hot summer sun on the bronze castings. The humidity is very high at all times and water is always present in standing pools and as condensate on the cooler surfaces.

Exposed to this hostile environment is a combination of metals consisting of large areas of bronze and brass of various compositions and very small areas of a tin-silver alloy, copper, nickel, and gold. Some steel may also be present. Also present is residual material from the casting molds, mostly gypsum and sand.

The concern is that this combination of materials and environment will result in detrimental corrosion, especially in the pores extending from the interior to the exterior lacquer. There is also the concern that alternate freezing and thawing of water in these pores will disrupt the lacquer seal and, hence, contribute to deterioration of the exterior appearance.

An Evaluation of the Problem

Brass and bronze are known to withstand weathering and many wet environments very wel1. Those knowledgeable about corrosion of copper alloys are agreed that the general interior surfaces of the bronze 
castings can be expected to satisfactorily withstand the action of the interior environment. The same can be said of the brass members that have been installed for structural purposes.

The corrosion engineer always concerns himself with the contact of dissimilar metals. Again there is agreement that the combinations of brass and bronze of various compositions are not expected to have adverse effects. Nor is the presence of small areas of tin-silver alloy considered detrimental, though not with complete assurance.

The specific concerns are the pores and cracks extending through the bronze castings, especially at the junctions of flanges of neighboring sections. Those pores and cracks which are open to the exterior are passages for water carrying gypsum and corrosion products from the interior to the exterior. Such passages have already been encountered as evidenced by white deposits on the exterior surfaces. If these pores are cleaned out and plugged with Incralac, they can be satisfactorily controlled. If such a maintenance program is not followed, then there will be a problem.

At the exterior end of a pore is a potential source of trouble. Here is to be found a combination of gold, nickel, and bronze and if this combination of metals is exposed to water, very serious corrosion will occur. The purpose of the exterior lacquer coating is to cover the gold and nickel, especially near exposed bronze so that water would be excluded from the areas where the 3 metals might contact each other. The problem is that all such areas may not have received an adherent coat of lacquer or some may become exposed by the action of the elements such as the freezing and thawing of water in pores. 
The Need for an Interior Organic Coating

The maintenance prograin which we have recommended anticipates the open pores and the gradual removal of Incralac by external weathering. It also provides for those defects arising from other causes, but only as infrequent occurrences. If the disruption of the lacquer from interior conditions should prove to be very frequent, then the maintenance program could be ineffective.

Since the completion in January 1972 of the refinishing of Music and Harvest and of Aspiration and Literature, a number of white gypsum and green-blue corrosion deposits have formed as was expected. The white spots might have been prevented by an interior coating. The greenblue formations may have been associated with pores extending through the castings, but an interior coating would probably not have prevented this corrosion since it is most likely that water got to the gold-nickelbronze junctions from the exterior.

There has been a suggestion that the darkening observed on two of the statues in $10 c a 7$ areas may be due to corrosive action from the interior. This is very unlikely. There is no evidence of such generalized porosity. Also if corrosion were to occur over such extensive areas, one would expect the lacquer to blister or lift off. This has not occurred.

Our opinion is that there is little evidence yet for the need of an interior coating. It is possible that such a need may become evident, but we feel that is unlikely. 
The Benefits of an Interior Organic Coating

Though there may be no apparent need for an interior coating, it may still be desirable. It could prevent some unforeseen corrosion problems or it might be regarded as insurance or an extra precaution. It is unlikely that an organic coating would do any harm, at least not the ones mentioned later in this report, and it might prove to be worth the extra cost and effort involved.

One objection to an organic coating that has been made is that a corrosion problem could develop underneath the coating and go undetected. This seems unlikely for several reasons. The only corrosion problems we anticipate are those involving the gold and nickel on the exterior. Such corrosion could never be evident in the interior of the statue. We should, perhaps, consider the unanticipated corrosion problems in the interior. A transparent coating like Incralac would not hide a corrosion problem.

A heavy bituminous coating would probably hide a corrosion problem. The polysulfide rubber-polyurethane system suggested in the next section of this report could be expected to hinder observation of a mild corrosion problem, but would probably visibly lift or blister if the corrosion were extensive.

There is one situation for which we do recommend an organic coating. If on future inspections, corrosion deposits are found on the exterior surface and if there is any indication that it may be associated with a crack or pore extending to the interior, then the corresponding interior surface, if accessible, should be given an organic coating to plug up the pores and cracks from the inside. 
Coating Materials

Many coating systems have been suggested and discussed for the interior of these statues and there are probabiy many that could be used. There are two which have come to our attention from more than one source. One is Incralac and the other is magriesium chromate inhibited poly sulfide rubber with a clear polyurethane overcoat. The latter has been recommended to NCP by Mr. Goldberg of the Naval Air Systems Command and by Mr. Wilburn A. Boggs, Corrosion Engineer of Lockheed-Georgia Co.

Since the purpose of painting the interior is to plug the pores, rather than to protect the bronze, consideration should be given to emulsion coatings (coal tar, asphalt, or latex emulsions). These are water base systems and as such would not involve the hazards of organic solvents during application. They might be effective at plugging pores, even though they do not constitute good corrosion preventive systems.

Summary

There is no positive indication for the need of an interior organic coating and, in our opinion, a catastrophic corrosion failure could not occur in the near future. Our recommendation, therefore, is that no organic coating be applied this year, and that we keep the statues under close observation until the fall of 1974 and see what corrosion problems develop. If a chronic corrosion becomes evident or if NCP wishes to take the extra precaution, then interior coating would be in order, especialty on surfaces corresponding to exterior areas showing porosity 
$-7-$

corrosion.

We also feel there is merit to a suggestion that has come from several sources. That is to paint a portion of the interior of one statue and observe the consequences during the following years. These observations might be very informative and give the guidance the NCP is looking for. We should point out that such a trial with a water base paint would be relatively inexpensive.

In preparing this report, little consideration was given to the economics involved or to the hazards of applying organic coatings in an essentially closed chamber. This latter consideration, of course, is of overriding importance. 


\begin{tabular}{|c|c|c|}
\hline $\begin{array}{l}\text { BIBLIOCRAPHIC DATA } \\
\text { SHEET }\end{array}$ & NBSIR 73-405 & \\
\hline \multirow{2}{*}{\multicolumn{2}{|c|}{$\begin{array}{l}\text { TITLI: AND } \\
\text { USE OF. ORGANIC COATINGS ON THE INTERIOR SURFACES OF } \\
\text { EQUESTRIAN STATUES AT MEMORIAL BRIDGE PLAZA }\end{array}$}} & $\begin{array}{l}\text { 5. Publication Darc } \\
\text { November } 1973\end{array}$ \\
\hline & & 6. Performing Organization Code \\
\hline \multicolumn{2}{|c|}{ - AUrllOR(S) Fielding Ogburn } & $\begin{array}{l}\text { 8. Performing Urgan. Re port No. } \\
\text { November } 1973\end{array}$ \\
\hline \multirow{2}{*}{\multicolumn{2}{|c|}{$\begin{array}{l}\text { PERFORMING ORCIANIZATION NAME AND ADITRESS } \\
\text { NATIONAL BUREAU OF STANDARDS } \\
\text { OEPARTMENT OF COMMERCE } \\
\text { WASHINGTON, D.C. } 20234\end{array}$}} & $\begin{array}{l}\text { 10. Projece Task/Work linit No. } \\
3120464 \text { (NBS) }\end{array}$ \\
\hline & & $\longdiv { 1 1 . \text { Contract, Grant No. } }$ \\
\hline \multirow{2}{*}{\multicolumn{2}{|c|}{$\begin{array}{l}\text { 2. Fintoring (Triuizution Vame and Complete Audress (Street, City, State, ZIP) } \\
\text { National Capital Parks } \\
\text { U. S. Department of Interior } \\
\text { Washington, U. C. } 20242\end{array}$}} & $\begin{array}{l}\text { 13. Type of Report \& Period } \\
\text { Covered } \\
\text { Final }\end{array}$ \\
\hline & & 14. Sponsoring Agency Code \\
\hline
\end{tabular}

\section{SLPPLEMENTARY NOTES}

5. ABSTKACT (A 200-word or less tactual summary of most significant information. If document includes a significant bibliography or literature survey, mention it here.)

The equestrian statues at Memorial Bridge Plaza in the District of Columbia are bronze castings. The exterior finish is subject to corrosion processes associated with pores and cracks in the castings. The interior surfaces are subjected to high humidity and condensation. Detrimental corrosion is expected only at discontinuities in the plated coatings on the exterior surfaces. Painting of interior surfaces has been recommended, but the need for painting is not clear. The NCP is advised to keep the statues under close observation till the fall of 1974 and then reconsider their course of action.

- KEY WORDS (six to twelve entries; alphabetical order; capitalize only the first letter of the first key word unless a proper name; separated by semicolons)

\section{bronze statuary; organic coatings; restoration; statues}

\begin{tabular}{|c|c|c|}
\hline $\begin{array}{l}\text { 3. AlAILABILITY U Unlimited } \\
\text { [- For Official Distribution. Do Not Release to NTIS }\end{array}$ & $\begin{array}{l}\text { 19. SECURITY CI_ASS } \\
\text { (THIS REPURT) } \\
\text { UNCL ASSIFIED }\end{array}$ & $\begin{array}{c}\text { 21. NO. OF PAGES } \\
7\end{array}$ \\
\hline $\begin{array}{l}\text { - Orjer From Sup. of Doc., U.S. Government Printing Office } \\
\text { Washington, 1).C. 20.502, Sil (ae. No. C13 }\end{array}$ & $\begin{array}{l}\text { 20. SE.CURITY CLASS } \\
\text { (THIS PAGE) }\end{array}$ & 22. Price \\
\hline $\begin{array}{l}\text { [-order From Nurional Technical Informarion Service (NTIS) } \\
\text { Springlicld, Virginid 22151 }\end{array}$ & UNCLASSIFIEU & \\
\hline
\end{tabular}




